\title{
Educação e primeiros letramentos no Brasil: redução cultural indígena
}

\author{
Education and first literacies in Brazil: indigenous cultural reduction
}

Educación y primeras alfabetizaciones en Brasil: reducción cultural indígena

\author{
GUILHERME Lima CARDOZO \\ ASSociaÇão Carioca de EnSINO SUPERIOR, UNICARIOCA, Rio de JANEIRO-RJ, BRASIL \\ UNIVERSIDADE ESTÁCIO DE SÁ, UNESA, RIO DE JANEIRO-RJ, BRASIL
}

\begin{abstract}
RESUMO
Este artigo traz à tona o empreendimento jesuítico no Brasil do século XVI, cujas estratégias colonizadoras iam muito além da religião, da política, da cultura, atingindo propriamente as diversas línguas nativas. A revolução linguística que os portugueses implantaram em terras brasileiras modificou o quadro social vigente, visto que as línguas indígenas, ao passo que eram aprendidas pelos padres jesuítas, entravam em processo de redução, a fim de serem catalogadas em uma gramática geral. Esta pesquisa mostra como a língua portuguesa, desde a chegada dos jesuítas, transforma-se, paulatinamente, em uma língua de herança, através dos letramentos de pequenos curumins, que com o tempo passavam a usar mais o português que sua língua materna. O documento denominado Ratio Studiorum pautará as ações de letramento jesuíticas, deixando claro que, apesar de todas as obras produzidas em língua nativa pelos padres, especialmente José de Anchieta, o plano jesuítico sempre fora legar as manifestações nativas ao esquecimento, impondo o português como língua oficial no Brasil.
\end{abstract}

Palavras-chave: Jesuítas. Linguística. Herança. Português. Indígena.

\begin{abstract}
This article brings the Jesuits undertaking to light in sixteenth-century Brazil, whose colonizing strategies went far beyond religion, policy, culture, reaching properly the various natives languages. The linguistic revolution which Portuguese's implanted in Brazil modified the social framework in force, because indigenous languages, while they were learned by Jesuit Fathers, were in process of reducing, to be cataloged in a general grammar. This research shows how Portuguese language, since the arrival of Jesuits, becomes, gradually, in heritage language, through literacy of native children, who over time they used more Portuguese than their first language. The document named Ratio Studiorum will guide the Jesuit actions of literacy, making clear, despite of all the works produced by Fathers in native language, specially José de Anchieta, the main Jesuit plan was bequeath to oblivion native manifestations, imposing the Portuguese as the official language in Brazil.
\end{abstract}

Keywords: Jesuits. Linguistic. Portuguese. Heritage. Indigenous.

\section{RESUMEN}

Este artículo trae el emprendimiento jesuítico en el Brasil del siglo XVI, cuyas estrategias colonizadoras iban mucho más allá de la religión, de la política, de la cultura, alcanzando propiamente las diversas lenguas nativas. La revolución lingüística que los portugueses hicieran en suelo brasileño modificó la composición actual, ya que las lenguas indígenas, mientras que eran aprendidas por los padres jesuitas, entraban en proceso de reducción, a fin de ser catalogadas en una gramática general. Esta investigación muestra cómo los portugueses, desde la llegada de los jesuitas, se convierten, poco a poco, en una lengua de herencia, a través de la educación de pequeños indígenas que, con el tiempo, se mantenían firmes al uso del portugués más que su lengua materna. El documento - Ratio Studiorum - pautará las acciones de alfabetización de los jesuitas, por lo que es evidente que, a pesar de todas las obras producidas en lengua materna por parte de sacerdotes, en especial José de Anchieta, el plan de los Jesuitas siempre había sido legar manifestaciones nativas al olvido, imponiendo el portugués como lengua oficial en Brasil.

Palabras clave: Jesuitas. Lingüística. Portugués. Herencia. Indígena.

\footnotetext{
${ }^{1}$ Professor adjunto da UniCarioca e professor auxiliar da UNESA. E-mail: guilhermegoldenstein@ gmail.com
} 


\section{INTRODUÇÃO}

O mito do descobrimento do Brasil, tão arraigado no imaginário popular que, às vezes, soa até como verdade, é o pai de todos os mitos em "terras tupiniquins": o mito do lusotropicalismo ${ }^{2}$, o mito da Língua-Geral, do bom colono, de uma língua nativa como língua nacional (ou mesmo como segunda língua), entre dezenas de outros, que até hoje escondem os reais fatores de colonização do território brasileiro pelos portugueses. Pretende-se, aqui, pontuar as estratégias dos colonizadores para que a língua portuguesa se tornasse língua de herança dos povos nativos, bem como expor um pouco do que chamamos "redução cultural indígena", por meio das diversas fases do letramento da população brasileira, especialmente no período em que a Companhia de Jesus liderou e estruturou esse processo. Destaques para o papel desbravador do padre José de Anchieta, cujo trabalho entre os povos nativos de diversas tribos resultou em inúmeras obras, as quais abrangiam as áreas da fonética, da morfossintaxe, da semântica, bem como da poética e da literatura. A maioria dos escritos de Anchieta impulsionava o que denominamos perspectivismo metalinguístico, onde, por meio da força e do poder de agente colonizador, todos os signos linguísticos nativos eram reduzidos pelo jogo da (re)significação jesuítica.

$\mathrm{Na}$ primeira parte deste artigo apresento o documento oficial da Companhia de Jesus que regia os processos de colonização religiosa, política e linguística: o Ratio Atque Institutio Studiorum Societatis Jesu (doravante Ratio Studiorum). Por meio das diretrizes expressas no documento, os novos padres jesuítas eram instruídos no aprendizado de diversas línguas, além de outras matérias ligadas às artes da filosofia, matemática e política. De fato não se formavam apenas oradores, prosélitos, mas homens com conhecimento profícuo acerca de ciências que iam muito além da religião. Uma nova empreitada da Igreja Católica Apostólica Romana para, de certo, rever conceitos ultrapassados e, sobretudo, formar uma renovada consciência, haja vista a Reforma Protestante vigente, e a necessidade de uma Contrarreforma. A escola dos jesuítas, que tinha a regência do padre Inácio de Loyola, também se preparava para conquistas muito maiores: com o advento das grandes navegações, Portugal se condicionava às novas conquistas territoriais, e os padres jesuítas, que possuíam um diferencial epistemológico em relação aos outros membros da Igreja, teriam a preponderante missão de estudar língua e cultura dos povos colonizados, incitando sua conversão e empreendendo a língua portuguesa como língua materna das novas gerações, tudo isso fundamentado nas diretrizes do Ratio Studiorum.

\section{O RATIO STUDIORUM}

Em 1548, o padre Inácio de Loyola elabora junto à Companhia de Jesus este plano de estudos para os ingressantes no Colégio dos Jesuítas, o Ratio Studiorum. O cerne deste ordenamento era garantir a uniformidade de procedimentos, de mente e coração dos educadores jesuítas e dos alunos, para a consecução dos objetivos propostos, quais sejam, as colonizações religiosa, política e linguística. Um ano após a elaboração do documento, os jesuítas desembarcaram no Brasil para a catequização dos nativos. Foi o padre Manuel da Nóbrega quem chefiou a primeira missão jesuítica no Brasil, fundando

\footnotetext{
${ }^{2}$ Termo cunhado pelo cientista social brasileiro Gilberto Freyre, através do que afirma ser a capacidade dos portugueses em adaptar-se aos ambientes dos trópicos, por empatia inata e plasticidade intrínseca, valores inerentes à sua natureza bicontinental (fruto do contato com mouros e judeus, durante muitos séculos).
} 
assim a primeira escola no país, mais precisamente em Salvador, Bahia (CARDOZO, 2016a).

O eminente padre Leonel Franca, doutor em teologia e sacerdote da Companhia de Jesus, legou-nos uma obra publicada postumamente chamada $O$ método pedagógico dos jesuítas, onde, entre outras lições, apresenta essa metodologia, denominada de Ratio Studiorum, como um ditame a ser seguido fidedignamente pelos educadores jesuítas, onde quer que estivessem. Afirma o padre Leonel Franca:

\begin{abstract}
A formação religiosa configurava-se como o maior pilar do sistema educativo jesuítico. Cuidava-se para que a fidelidade doutrinária fosse mantida, irrestritamente, evitando-se quaisquer textos, autores, questões polêmicas ou debates em discordância com a doutrina da Igreja, para que nada expusesse a fé e a piedade dos alunos. [...] O Ratio Studiorum [...] se adapta bem às exigências do seu tempo; tudo o que tinha um valor no mundo científico do século XVI foi nele levado em consideração. Não duvido tampouco, que pela organização escolar, a Ordem tenha promovido eficazmente a difusão da cultura intelectual, e, em particular, o conhecimento das línguas clássicas nos países católicos, onde os jesuítas eram os mestres mais instruídos e mais zelosos (FRANCA, 1952, p. 55-56).
\end{abstract}

Esses aspectos trazidos pelo padre Leonel Franca demonstram a inflexibilidade dos preceitos jesuíticos, quanto aos seus métodos de ensino do Evangelho, mormente no que diz respeito ao afastamento de questões polêmicas na educação catequética dos povos colonizados. O advérbio "irrestritamente", nos primeiros contatos entre ameríndios e jesuítas no Brasil, revelava uma falsa eficácia na conversão dos nativos, e neste ponto nevrálgico se destacam as figuras dos padres Manuel da Nóbrega e José de Anchieta como grandes tradutores culturais - o último se destaca por também ser um conhecedor da língua dos nativos - e, portanto, tidos em grande conta por parte da maioria das tribos e aldeias da costa sul brasileira. Ambos os jesuítas perceberam que as restrições, se não fossem flexibilizadas pela Companhia de Jesus, não permitiriam um alcance eficiente da doutrina cristã aos "selvagens da terra", porquanto não abdicavam tão facilmente dos seus costumes, mesmo que, aparentemente, se maravilhassem com as mensagens dos missionários.

A missão dos jesuítas no Brasil é importantíssima sob o ponto de vista político, pois a Ordem dos Jesuítas é produto de um interesse mútuo entre a Coroa de Portugal e o Papado, visto que era útil à Igreja e ao Estado emergente. Ambos pretendem expandir o mundo, defender as novas fronteiras, somar forças, integrar interesses leigos e cristãos, organizar o trabalho do Novo Mundo pela força da unidade lei-rei-fé.

É claro que não colocaremos em cheque a intenção primeira das missões jesuíticas, a qual se resume na empresa colonizadora em âmbitos linguísticos, culturais, religiosos, por conseguinte econômicos e políticos, já que a Companhia de Jesus representava em solo brasileiro a Igreja e a Coroa portuguesas (CARDOZO, 2016b, p. 60).

\title{
ESTÁGIOS DOS PRIMEIROS LETRAMENTOS
}

Os primeiros letramentos, regidos pelo Ratio Studiorum, realizaram uma revolução metalinguística na colônia: delimitaram o que era a "língua mais falada da região", bem como deram uma escrita a esta língua oral, e por fim lhe forneceram uma sintaxe portuguesa. O resultado dessa empreitada foi a convencionada "Língua-Geral", a qual ganhou uma gramática e alguma literatura.

Em suma, os primeiros letramentos se davam em três estágios: 

cristã;

1) Catequese e ensino de Latim por meio da leitura e ensinamento da doutrina

2) Ensino de leitura e escrita da língua portuguesa para fins de comunicação entre colonizador e colonizado;

3) Necessidade de se aprender as línguas nativas (um dos preceitos do Ratio Studiorum), para facilitar as traduções (CARDOZO, 2016a).

Não obstante alguns raros comentários em favor de uma autonomia dos padrões linguísticos da língua Tupi, era lugar-comum a ideia de que uma "língua civilizada", portanto um "homem civilizado", não poderia nascer de culturas e línguas "tão brutas e primitivas", daí serem o Latim e o português meios necessários para a formação da ocidentalização do homem "primitivo". Dessa forma, com a instalação dos Colégios dos Jesuítas, em 1549, ensino e conversão nascem juntos. O padre Manuel da Nóbrega foi um importante nome no papel de catequese dos nativos brasis, mas não possuía a visão linguística que caracterizou o trabalho do padre Anchieta. Nóbrega se destacou ao perceber a função da música nas comunidades tribais e, desde então, adotara a pregação da Bíblia permeada por cânticos - muitos deles à moda indígena (o que muito irritava os padres e bispos que serviam de porta-vozes do Reino Português), mas no que respeita aos processos linguísticos e tradutórios, o padre José de Anchieta foi personagem fundamental no estabelecimento do saber metalinguístico brasileiro (CARDOZO, 2016a). O padre Nóbrega, ao contrário de seu colega jesuíta, não enxergava o terreno fértil para a criação de um espaço onde a doutrina cristã fosse bem pregada:

Temos determinado de ir viver com elles nas aldeias, como estivermos mais assentados e seguros, e aprender com elles a língua e il-os doutrinando pouco a pouco. Trabalhei por tirar em sua língua as orações e algumas práticas de Nosso Senhor e não posso achar língua que m'o saiba dizer, porque são elles tão brutos que nem vocábulos têm (NÓBREGA citado por SILVA, 2001, p. $145)$.

Com a chegada do padre Anchieta, em 1553, ao Brasil, a relação ensinoconversão-língua (SILVA, 2001) se fortalece e se aprofunda, através dos autos e peças teatrais, sermões catequéticos, poemas, cartas e, em especial, gramática e dicionários.

\section{EMPECILHOS PARA OS LETRAMENTOS}

O Ratio Studiorum prescrevia a necessidade de se aprenderem as línguas nativas, a fim de descrevê-las e normatizá-las, todavia vários fatores serviram de empecilho em um primeiro momento nas tentativas de letramento: o primeiro era a extensão territorial do novo mundo, o que contrastava com o pequeno número de padres jesuítas preparados para o trabalho mais linguístico que catequético; o segundo era a diversidade linguística incomensurável, o que impedia um trabalho preciso de descrição linguística da colônia: estima-se que à época da chegada da Companhia de Jesus ao Brasil, havia cerca de mil e quinhentas línguas diferentes em todo o território; junto a isso, os troncos linguísticos ${ }^{3}$ que davam origem às línguas nativas não se pareciam em nada com os idiomas aprendidos pelos padres no Colégio dos Jesuítas. Ou seja, ao contrário do que se referendou pelos jesuítas, o Tupi não é uma língua, tampouco a língua mais falada pelos nativos brasis. Essas línguas do tronco Tupi possuíam alguma semelhança entre si, talvez da mesma forma como as línguas derivadas do tronco latino se assemelham. Essa aproximação virtual entre as línguas foi uma das prováveis razões de sua redução à

\footnotetext{
${ }^{3}$ Rodrigues (2013) afirma que existem dois troncos de línguas indígenas no Brasil: o Tupi e Macrô-Jê.
} 
língua imaginária, denominada "Língua-Geral". O mito dessa língua configurou-se um decisivo passo na destruição da cultura genuinamente brasileira (CARDOZO, 2016a).

Outro problema era a ausência de escrita das línguas indígenas, o que dificultava a análise comparativa - por exemplo, em Goa (Índia), os jesuítas encontraram uma língua nativa com escrita, o Tâmul; não suficiente todas essas questões, a diferença ontológica entre portugueses e indígenas sobressaltava: costumes nativos como as guerras de vingança, a poligamia, os ritos próprios (como as festas de cauim), o respeito aos profetas da terra (karaíbas), a busca da Terra sem Mal, o canibalismo presente em algumas tribos, além da obsessão onomástica, desenhavam-se como verdadeiros entraves à empresa colonialista. Portanto, necessário era dizimar completamente esses costumes, para que se pudesse enraizar a cultura ocidental, em especial a doutrina cristã. É nesse cenário que se pode compreender o "efeito Anchieta" como o divisor de águas no processo catequético do Brasil no século XVI (CARDOZO, 2016a).

\section{O EFEITO ANCHIETA}

Em 1553, o padre jesuíta José de Anchieta desembarca no Brasil, permanecendo, primeiramente, em Salvador, na Bahia, e logo depois partindo para São Paulo, onde, um ano depois, funda a primeira escola da região. A habilidade linguística de Anchieta fez com que, em pouco tempo de convivência com os nativos, aprendesse grande parte das línguas faladas naquela região brasileira, o que obviamente facilitou a relação ensinoaprendizagem entre indígenas e jesuítas, tornando o Colégio de São Paulo proeminente no ensino de línguas e catequese (CARDOZO, 2016a).

Um grande feito que abrangeu as áreas linguística, cultural e religiosa foram as composições de José de Anchieta em língua nativa: o padre jesuíta percebeu a necessidade de se falar a "língua do índio" e passou a compor liturgias, peças de teatro, orações, catecismos e canções na língua dos nativos, o que garantiu a Anchieta, de certa forma, prestígio entre algumas tribos. Esse minucioso trabalho de campo culminou na elaboração da Artes de Gramática da Língua Mais Usada na Costa do Brasil (ANCHIETA, 1990), o que direcionou os letramentos ulteriores em toda a colônia.

A gramática aparece como mero instrumento de domesticação cultural e religiosa, da mesma forma os dicionários, os textos escritos, as peças teatrais anchietanas, todos esses elementos dirigidos a outros sujeitos que não os grupos tribais, dos quais se furtava o direito de interagir, intervir e reinventar essa nova realidade linguística da colônia. Quanto à Arte de Anchieta, é vista por Borges (2001) como um trabalho de domesticação, encobrimento e transmutação ideológico-discursiva da cultura tupi, o que indica que o trabalho realizado pelos jesuítas se resume a uma captura do conhecimento e da tecnologia dos povos indígenas, com fins de construir uma nova ordem discursiva nas condições históricas da época, e não deve ser confundido com uma valorização da cultura tupi.

\section{A ARTE DE GRAMÁTICA}

Com a gramática elaborada pelo padre José de Anchieta para a língua dos nativos brasileiros, sedimenta-se o mito de que haveria uma língua mais falada do que outras, e de que todos os indígenas soubessem essa "língua-geral". Se a catequese já significava um processo de redução cultural indígena, o letramento por meio da Arte de Gramática conduzia a um violento processo de redução linguística.

Vale destacar as condições que levaram missionários como José de Anchieta a descrever prioritariamente a língua que denominou a mais usada na costa do Brasil: em 
1557, nas regiões de Ilhéus e Porto Seguro, na Bahia, Mem de Sá mandou destruir mais de cento e trinta tribos falantes de línguas do tronco Tupi; e mesmo que a região da capitania de São Vicente ainda conservasse tribos falantes dessas línguas, aproximadamente entre 1557 e 1584 essas mesmas tribos foram aniquiladas, dando lugar a tribos como os Aimoré, falantes do "tapuya" - ou seja, não falavam esta variedade linguística do Tupi, mas outra completamente diferente. José de Anchieta, amparado pelo convívio com os falantes de Tupi, redigiu os Vocabulário na Língua Brasílica e a Artes de gramática, fundamentado em seus estudos com essas tribos (CARDOZO, 2016a).

O jesuíta Fernão Cardim, em seu Tratados da terra e gente do Brasil, de 1584, aponta algumas situações linguísticas que ocorriam na costa brasileira e que servem de subsídio para as escolhas feitas por Anchieta em sua gramática:

\begin{abstract}
Em toda esta província ha muitas e varias noções de differentes línguas, porém huma é a principal que comprehende algumas dez nações de Índios: estes vivem na costa do mar, e em uma grande corda do sertão, porém são todos estes de uma só língua ainda que em algumas palavras discrepão e esta é a que entendem os Portuguezes. A língoa da costa é fácil, e elegante, e suave, e copiosa, a dificuldade della está em ter muitas composições. [...] Todas estas setenta e seis nações de Tapuyas que têm as mais differentes, são gente brava, silvestre e indómita, são contrarias quasi todas do gentio que vive na costa do mar, vizinhos dos Portugueses... D'estes há muitos christãos... e somente com estes Tapuyas se pode fazer algum fructo; com os demais Tapuyas, não se pode fazer conversão por serem muito andejos e terem muitas e differentes lingoas difficultosas (CARDIM, 1978, p. 121).
\end{abstract}

Uma suposta homogeneidade rondava o imaginário do português falante de um tupi instrumental, e havia certo prestígio ao índio da costa brasileira, tanto por seu falar "homogêneo", o que tornava a língua "fácil", "elegante" e "suave", conforme descreve o jesuíta Fernão Cardim. O tratamento com outras tribos era diferente, principalmente por seu falar diversificado, o que lhes atribuía características antagônicas às dos índios da costa (eram os Tapuyuas "selvagens" e "indómitos"). Acerca dos mesmos Aimorés, que passaram a viver na região de São Vicente nos fins do século XVI, afirma o missionário Gabriel Soares de Sousa:

E são estes Aimorés tão selvagens... a sua fala é rouca da voz, a qual arrancam da garganta com muita força... [ao contrário dos Tupinambá que] têm muita graça quando falam, mormente as mulheres; são mui compendiosas na forma da linguagem, e muito copiosas no seu orar (SOARES DE SOUSA, 1587, p. 302).

Falando da gramática propriamente dita de Anchieta, esta conta com dezesseis capítulos, com uma atenção especial à ortografia e à fonologia. Mesmo que se encontrem muitas observações quanto a regras morfossintáticas nas outras seções da arte de gramática, ela segue uma ordem comum, com fonologia e ortografia antecedendo a morfologia: esta começa com os nomes, após pronomes e verbos são descritos com detalhes. Ressalva feita às preposições que gozam de um capítulo específico (o capítulo X) no meio das análises, do XII ao XVI, padre Anchieta dedicou à análise dos verbos em Tupi, onde também são feitos comentários avulsos acerca das outras partes do discurso, como os advérbios, as interjeições, os particípios e as conjunções, visto que, segundo o jesuíta, esses elementos não comparecem na realidade linguística nativa. Da mesma forma, a sintaxe não goza de um capítulo específico, mas se espalha por entre os dezesseis (CARDOZO, 2016a). 
Apesar de o Latim estar sempre presente no imaginário de Anchieta, pode-se dizer que percebeu que muitas categorias latinas eram inapropriadas ao Tupi, fato que fez com que sua gramática se diferençasse das demais - criou capítulos de uma morfossintaxe estritamente Tupi. Ao contrário de outros gramáticos da época, Anchieta não faz menção aos clássicos, tampouco aos seus métodos, o que corrobora com seu estilo de composição inovador e diferenciado (CARDOZO, 2016a).

As gramáticas missionárias possuíam todas as características de uma gramática laica, a saber: seus aspectos técnicos muito bem definidos, sua descrição minuciosa de algumas variantes linguísticas nativas, seu aspecto pedagógico para o ensino e o aprendizado, entre outras causas. Quem corrobora esta afirmativa é o tupinólogo J. J. Philipson, através de seu trabalho Por que estudar Tupi-Guarani?, publicado em 1957:

Creio que a Arte de Anchieta resiste a todas as críticas, desde que se leve em conta a época em que foi feita. É uma gramática que, embora decalcada sobre o latim, não o é tanto quanto geralmente se pensa, pois tantos são os dados específicos e novos, que de forma alguma poderiam constar, se o autor se tivesse limitado a preencher os vazios de um esquema preconcebido. $\mathrm{O}$ fator tempo que hoje dificulta muitas vezes o trabalho de campo de etnólogos e linguistas não entrava em consideração para Anchieta e seus muitos colegas de catequese, que tiveram, ao que tudo indica, um bom speaking knowledge (conhecimento de falar) da nova língua (PHILIPSON citado por DRUMOND, 1990, p. 11).

Outro grande conhecedor do Tupi, Professor Frederico G. Edelweiss, em sua obra Estudos Tupis e Tupi-Guaranis, ratifica o exposto:

\begin{abstract}
Outro ponto dificilmente contestável é a presença da gramática latina nos espírito dos tupinistas inacianos em suas elucubrações linguísticas. Entretanto, concluir daí que a estrutura latina era por eles considerada o modelo e que, para melhorar o tupi, o disciplinaram pela gramática latina é ultrapassar os limites. É uma afirmação não apenas impossível de provar, mas ilógica, porque tais alterações dificultariam grandemente a evangelização, somando, para gente bronca, o abstruso de concepções religiosas, tão diferentes, à sua transmissão em linguagem desajustada com a dos índios. A história mostra que o jesuíta não anularia grande parte do seu esforço pela falta de adaptação linguística adequada. Ao contrário, esse preparo, segundo a declaração expressa de Antônio Vieira, foi sempre exigência primordial entre os jesuítas, ao ponto de sobreporem, para os missionários, o conhecimento do tupi ao do latim desde o tempo de Nóbrega e de admitirem de preferência elementos conhecedores do tupi, por haverem convivido com os índios [...]. A que se reduz então a latinização do tupi pelos jesuítas? Exclusivamente à terminologia e à disposição da gramática (EDELWEISS, 1969, p. 11-12).
\end{abstract}

Essas sentenças confirmam a tese da revolução tecnológica gramatical iniciada pelos jesuítas no Brasil, especialmente pelo padre Anchieta. Não obstante o rasgo epistemológico anchietano quanto a uma dependência estrutural das gramáticas latinas, não se deve negligenciar que a pedagogia dessas gramáticas apresentava fatores catequistas espalhados pelos exemplos citados na gramática: a devoção aos bons costumes, o castigo, as proibições, todas as noções ligadas a Tupã estavam de alguma forma presentes nas obras de Anchieta. Por exemplo, no capítulo XVI, sobre verbos irregulares, há exemplos de frases que indicam a subserviência à figura do padre: "Toçôey padre, endèbe. Va, dis o padre a ti"; ou remetendo aos símbolos cristãos do paraíso celeste: "aicôcatû taçóne ibácupeyába, sou bom pera ir ao ceo"; alguns remontavam às pregações jesuítas contra as práticas de vingança em troca da cura por 
algum mal: "Oyepoçanôngucâr tapoeráne noyáho ruã. Cura-se para sarar, mas não há de sarar"; ou falando sobre os castigos: "Aporonupã, castigado", "Хeporonupã , costumo a castigar", "Xeporonupãjà xeporonupãjab̂̀, acostumo a çoutar muitas vezes", "Acanhêmja, costumo fugir a meude"; sobre a interpretação ocidental para os valores nativos: "naxêabaréi pagê xepagê, não sou padre, sou feiticeiro"; sobre os valores cristãos: "Aromanô tecocatû, morro com a virtude posto que ela não morra", "xecat $\hat{u}$, eu sou bom" (CARDOZO, 2016a).

O que se conclui, quanto às gramáticas missionárias, é que, se por um lado, há constantes traduções de catecismos espalhados por seus exemplos, há também um severo trabalho de descrição linguística, entretanto não somente isso. Segundo Hovdhaugen:

A gramática missionária esboçava um desenho bem preciso que compreendia, geralmente, a tradução das pregações, em seguida de um Catecismo, um livro das confissões e geralmente também um dicionário. Havia o intento de instruir os missionários que quisessem embarcar naquelas missões em terras distantes (HOVDHAUGEN citado por MURU, 2010, p. VIII).

E completa Cristina Muru (2010), pesquisadora italiana da consistência linguística das gramáticas missionárias:

\begin{abstract}
Aquilo a que as gramáticas missionárias se reportam, por exemplo, não são somente meras descrições linguísticas ou tentativas de redigir gramáticas pedagógicas. Frequentemente nas entrelinhas é possível recolher informações a respeito de estruturas organizacionais das sociedades dentro das quais eles [missionários] operavam. Descrição gramatical e etnografia são, portanto, os aspectos salientes deste ramo da linguística que é definida como linguística missionária (MURU, 2010, p. VIII).
\end{abstract}

É de se destacar que essa redução das línguas indígenas não se dava pela imposição das línguas latina e portuguesa, mas por um processo de metalinguagem da língua nativa. Podem-se elencar quatro procedimentos fulcrais para a empresa reducionista dos padres portugueses:

1) Reconhecimento do terreno linguístico: é com Anchieta que o terreno linguístico dos indígenas é investigado e descrito (mesmo que parcialmente). Com a severa doutrinação do Ratio Studiorum aos estudantes do Colégio dos Jesuítas, no que diz respeito ao ensino e aprendizado de línguas de diferentes troncos, era mister aprender e reconhecer os signos dos povos colonizados para reduzi-los, até o desaparecimento;

2) Descrição das línguas: a convivência com diferentes tribos permitiu aos jesuítas identificar elementos em comum entre as línguas faladas por cada uma delas. Antes de concluir a sua gramática, Anchieta e os outros jesuítas puderam se valer de outros documentos descritivos, mesmo que bastante superficiais, ou restritos ao campo lexical. Não obstante a pouca profundidade desses materiais, foram de importante auxílio na empreitada jesuítica de coleta de dados linguísticos, para fins metalinguísticos;

3) Redução das línguas: ao identificar uma série de palavras e/ou estruturas em sentenças da fala dos nativos, a habilidade linguística de Anchieta permitiu que ele condensasse diversos elementos das várias línguas com as quais teve contato em apenas uma língua, cujo nome não é em vão: "Língua-Geral". Uma língua fabricada, estereotipada, fruto da arbitrariedade de seus produtores. A subjetividade nas escolhas 
dos elementos léxicos, morfológicos e sintáticos que comporiam essa língua, reduzia quase que inteiramente o arcabouço de uma série de línguas do tronco Tupi;

4) Revoluções metalinguísticas: todo esse processo de reconhecimento, descrição e redução resultam nos processos de metalinguagem das diversas línguas indígenas condensadas na suposta "Língua-Geral". As línguas, que eram orais, passam a gozar de uma escrita - fato que gera estranhamento à cultura local; a nova língua escrita possui uma gramática, que descreve as suas peculiaridades fonéticas, morfológicas, com algumas observações no campo da sintaxe. Uma nova língua de léxico "Tupi” e sintaxe portuguesa emerge do (des)encontro entre indígenas brasis e jesuítas portugueses (CARDOZO, 2016a). O resultado é o surgimento da "língua Tupi", também chamado, segundo Luiz Borges (2001), de "tupi jesuítico".

\section{PROCESSO DE REDUÇÃo POR ONOMÁSTICA}

Apesar de a Arte de Gramática ser a revolução tecnológica por excelência desse conglomerado linguístico nativo, chamado de "língua Tupi", não é dentro dela que um dos processos de redução mais sensíveis das línguas indígenas se manifesta. Em obras do padre Anchieta, como A Lírica Tupi e a A Doutrina Cristã (volumes I e II), escritas tanto em português como em Tupi, fica nítido como a cultura e as línguas nativas foram violentadas por meio das ressignificações onomásticas. Abaixo seguem alguns exemplos desse processo de redução:

a) Añánga: segundo a cultura nativa, era um espírito antigo que guardava as florestas, e, conforme a crença de algumas tribos, manifestava-se nas cobras e onças, matando seus invasores. Após as ressignificações simbólicas feita pelos padres jesuítas, Añánga passa a ser o inimigo de Tupã, contrário a Jesus Cristo e difamador de Santa Maria. Sua figura é traduzida ao novo contexto linguístico-simbólico como "o diabo";

b) Tupã: consoante a cultura dos nativos, era uma entidade ligada às manifestações naturais que provinham do céu, como os trovões e as tempestades, e muito temida pelos indígenas. Após as ressignificações feitas pelos jesuítas, Tupã passa a assumir a figura de Deus único e criador do universo, contra quem peleja Añánga. Os trovões passaram a ser usados pelos jesuítas como manifestações de insatisfação ou ira de Deus para com as insubordinações dos indígenas;

c) Guaixará: conforme a cultura nativa, este era um antigo chefe dos indígenas Tamoio, tido com grande estima e respeito. Liderou muitos nativos contra os portugueses e em favor dos franceses. A reformulação simbólica dos jesuítas transformou Guaixará em um índio terrível, habitante dos infernos e a serviço de Añánga. Seu trabalho era influenciar os nativos contra o novo comportamento dos catequisados, em favor do retorno às práticas dos ancestrais;

d) Ratápe: para os da terra, era a fogueira localizada ao centro dos rituais e festas indígenas, onde os karaíbas entravam em transe, e os inimigos eram mortos e desmembrados para o ato antropofágico. Os jesuítas redimensionam o signo ratápe, dando-lhe a denotação de "inferno", o contrário de Ybakýpe - o Paraíso, ou a Terra sem Mal -, que representa algo muito desejado pelos nativos. Persistindo os indígenas nos rituais sugeridos pela velha significação da palavra ratápe, automaticamente perdiam seu paraíso;

e) Ybakýpe: não representava exatamente o símbolo da Terra sem Mal para a cultura nativa, até porque este era um símbolo Tupinambá. Entretanto, ybakýpe convocava um local de fartura e vida eterna, para gozo dos guerreiros honrados. Devido à convergência de sentido, os padres jesuítas trazem o conceito de Paraíso Cristão, Nova Jerusalém para o conceito de ybakýpe, local para onde vão os que não guerreiam, mas se 
convertem e se batizam, perdendo seus velhos nomes em troca de um novo nome, dado por um abaré (CARDOZO, 2016a).

\title{
A REDUÇÃO POR NEOLOGISMOS
}

Um procedimento interessante de que se valeram os jesuítas para reduzir as línguas indígenas foi a ampliação, ou a criação, de um campo lexical completamente novo, no que concernia à religião. O processo onomástico dos novos símbolos Tupi, inventados pelos jesuítas por meio da tradução dos signos cristãos, criou uma esfera simbólica tão incomum aos indígenas quanto aos próprios padres portugueses. Uma busca incessante por equivalentes entre entidades, conceitos e valores judaico-cristãos e indígenas, criando assim "[...] uma terceira esfera simbólica, uma espécie de mitologia paralela que só a situação colonial tornara possível” (BOSI, 1992, p. 65).

A onomástica passa a assumir um papel muito mais significativo do que antes se previa: com função de aproximar e traduzir as entidades cristãs aos Tupi, a onomástica, por meio dos neologismos criados por Anchieta, é a mola propulsora dessa terceira esfera simbólica entre colonizadores e colonizados. Como exemplo, as traduções de "céu" e "inferno", bem como de seus representantes:

\begin{abstract}
Para que a perspectiva religiosa europeia fosse inserida na cosmologia indígena, Tupã carecia de uma força oposta que representasse as trevas. Para tal, Anchieta escolheu "Anhanga" como o conceito de diabo. "Anhanga", no imaginário indígena, era o protetor da selva e dos animais e tinha poderes e habilidades surpreendentes, capaz de trocar de forma e atormentar os seres humanos. Neste novo padrão mitológico, Anhanga assumiu o papel do príncipe das trevas e era diretamente responsável por todos os maus hábitos do ameríndio (ALVES FILHO, 2010, p. 22).
\end{abstract}

Muito clara a intenção dos jesuítas em conectar as atividades que eles condenavam e consideravam diabólicas por parte dos indígenas a uma entidade que causava aos nativos um grande pavor. Alfredo Bosi (1992) observa essa estratégia de Anchieta como uma arma eficiente de combate aos "maus hábitos" nativos, pois generalizavam o medo presente nas divindades manifestadas em transes e cerimônias xamânicas. Um dos instrumentos utilizados por Anchieta para tal foi a grande presença da figura de Añánga em seus autos e peças teatrais, usando a entidade, então diabólica, para conceituar os rituais e o comportamento dos Tupi, discriminando-os como maléficos e contrários a Tupã. Assim, "[...] manipulando e traduzindo estes elementos, Anchieta reorganizou seus significados no imaginário nativo. Tupã, com seus poderes divinos de um lado, Anhanga e os costumes bárbaros, como poligamia e canibalismo, de outro" (ALVES FILHO, 2010, p. 23).

Neologismos como o da emblemática palavra karaibebé (karaí + bebé, onde o primeiro termo designa um "profeta índio" e o segundo o adjetivo "alado") apareciam com frequência na tradução dos dogmas e nomes cristãos para a "língua mais falada da costa". A ideia desta palavra era remeter o nativo ao conceito de "anjo", extremamente fugidio ao indígena. Bosi (1992) muito bem explana essa confusão:

A estratégia que Anchieta escolheu para transmitir o cristianismo frequentemente era a de procurar algum elemento correspondente entre os idiomas português e tupi. Contudo os resultados eram desiguais, como a tradução da palavra "anjo" por "karaibebe". Este neologismo deriva de "karai" (o profeta índio) e "bebé" (alado). Nesse sentido, o conceito era estranho ao índio e ao europeu: um profeta voador não era familiar ao nativo 
nem ilustrava adequadamente a figura de um anjo, segundo a definição bíblica (BOSI, 1992, p. 67).

Também é o caso da palavra "tekó-aíba", ou "tekó-angaipaba", ou também "tekópoxy", o que, através de um processo de formação de palavras, seguindo a uma ideologia estritamente católica-ocidental, designava o conceito de "pecado". Os três termos Tupi significam, a grosso modo, "vida ruim" ou "cultura ruim das pessoas", o que para a cultura/língua de chegada talvez não significasse nada, haja vista a ausência de valoração negativa das atividades condenadas pela Igreja (poligamia, canibalismo, guerras etc.); aliás, pelo contrário, eram relações necessárias: a poligamia não somente estava ligada à proeza guerreira do indígena, mas também a uma questão de utilidade e praticidade, pois que enquanto uma trabalhava no campo, a outra cuidava dos filhos, outra da aldeia etc. Desta forma, o conceito de pecado carecia de uma ordem mais significativa e abrangente de definições, pois, da forma que era concebida na cultura cristã-ocidental, não teria uma definição de "vida ruim" ou "cultura ruim das pessoas" para os povos ameríndios. Talvez por isso o termo ainda permaneça, em algumas traduções de sermões, orações e confissões, em sua forma original "pecado", como uma série de palavras que resistiam à tradução. Houve também, além da nomeação e atribuição da entidade "Anhanga" como o demônio, a tradução de "fogo" (representando o local infernal de sofrimento eterno) para o Tupi "ratá". Essa tradução se relacionava não com a substância natural fogo ("atá"), mas a prefixação "r" designava que esse fogo pertencia a Anhanga, portanto, um fogo aterrorizador; no intuito de designar a qualidade de "pureza", referente à Virgem Maria, portadora de valores a serem disseminados contra o comportamento sexual dos índios, Anchieta reuniu em uma palavra três noções do tupi: "moro-potar-e'yma", o que significava literalmente "Não desejar sensualmente as pessoas" (NAVARRO, 2001).

Em excertos da oração do "Pai Nosso", bem como nos Dez Mandamentos, traduzidos por Anchieta, encontramos também a manutenção de outras palavras em português, obedecendo à hierarquia descrita no Ratio Studiorum e referida por Robinson: "Eimoeté Domingo", (ANCHIETA, 1992, p. 143); "Orê rûb Ybàkupe tekóar, Ymoete pyramo,nde rera toikó nde de T'our Reino"” (NAVARRO, 2001, p. 62); “Ore moar ukar ume iepe Tentação pupé ${ }^{6}$ " (NAVARRO, 2001, p. 63).

Em alguns casos peculiares, Anchieta mesclava a tradução onomástica de "nomes superiores" - ou que deveriam ser proferidos nas línguas consideradas superiores - com o substantivo Tupi, ou até na mesma palavra inserindo um sufixo tupi em palavra portuguesa, caso de um de seus sermões, exaltando a santíssima Trindade: "Arobiar Túbamo sekó, arobiar Tayramo sekó, arobiar Espírito Sántoramo sekó "” (ANCHIETA, 1992, p. 149). A compreensão do conceito de "Espírito Santo", caro até mesmo a muitos cristãos, não conseguiria um equivalente semântico na língua de chegada, motivo pelo qual se mantém, neste caso, o nome em português - o que não ocorreu, por exemplo, com os elementos "Pai" e "Filho", da Trindade. Uma tentativa de melhor se fazer compreender o terceiro elemento "Espírito Santo" dá-se com a colocação de um sufixo tupi "ramo" na palavra em questão, significando "na condição de" Espírito Santo, enfatizando "[...] a condição desta entidade sobrenatural e assim tornando-a mais familiar ao público" (ALVES FILHO, 2010, p. 26). Helena Brandão (1978) afirma que esse recurso por parte do padre Anchieta assemelhava-se em muito às estratégias do

\footnotetext{
${ }^{4}$ Guardar o domingo.

${ }^{5}$ Pai nosso que estais no Céu, santificado seja o Vosso nome, venha a nós o Vosso Reino.

${ }^{6}$ Não nos deixe cair em Tentação.

${ }^{7}$ Acreditamos em Deus Pai, acreditamos em Deus Filho, acreditamos no Espírito Santo.
} 
Papa Gregório, na Inglaterra do século VIII, quando da tentativa de converter os pagãos ao cristianismo: "[...] suas instruções determinavam que elementos pagãos não deviam ser descartados e deviam ser adequados aos preceitos cristãos o máximo possível, pois acreditava que seria impossível extirpá-los de todo das almas consideradas 'ásperas' e "bárbaras"” (BRANDÃO, 1978, p. 14). A dificuldade frente aos nativos brasis estimulava a criatividade na tradução cultural realizada pelos jesuítas, e destacamos aqui como exemplo a peça "Recebimento do Padre Marçal Beliarte", datada de 1589, a qual mistura a aparição de "demônios" - denominação totalmente católica às divindades Tupi - com a presença da mãe de Deus (Tupãsy), teatralizando a recorrente luta entre o bem e o mal, muito enfatizada por Anchieta em suas obras. Os diálogos nesta obra estão em português e em Tupi. A língua nativa, além de aproximar o índio do enredo, também tinha grande poder de realocação simbólica: destruir o mito do indígena na língua do colonizador é "assassinato", mas fazê-lo na própria língua Tupi é "esclarecimento". Nesta obra, o padre Anchieta coloca em cena um elemento essencial da cultura nativa, distorcendo-o habilmente em relação ao seu significado original: Makaxera, um dos demônios representados, é assassinado no ritual antropofágico por um corajoso índio herói da estória - sob as ordens de Tupãsy. Destaca-se a fala da personagem heroica, o índio Añagupiara:

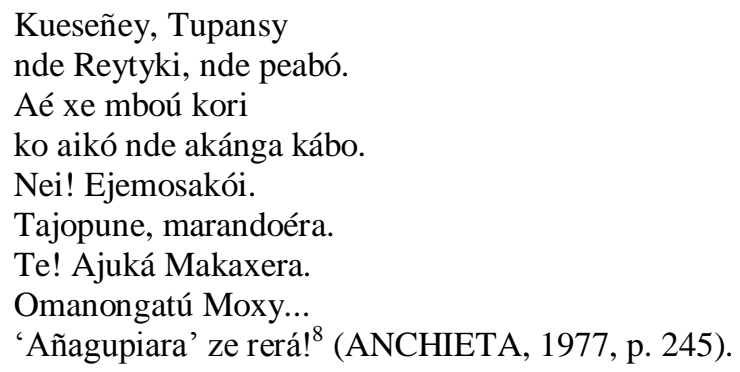

O jesuíta se reapropria dos valores, nomes e cultura ameríndios para realocá-los numa esfera simbólica diversa da nativa, conforme afirma Robinson (1997), ao dizer que '[...] as palavras do povo colonizado podem ser 'citadas', 'traduzidas', 'relidas' e 'reescritas' pelos colonizadores de modo a remodelar a cultura colonizada de acordo com os interesses da dominação" (p. 93). Não somente o nome Makaxera, mas a tradição indígena do canibalismo, da guerra e do traulitar o crânio se fazem presentes na peça do jesuíta, mas, desta feita, no intuito de ressignificá-la: se antes o ritual de sacrifício do cativo servia para nutrir as virtudes do guerreiro, ensejando a troca com o outro, no texto de Anchieta o mesmo ritual tem por fim afastar o mal que Makaxera, com todos os seus "costumes selvagens", representa. Querendo ou não, a mensagem missionária, antes adornada em sua totalidade do espírito de misericórdia, no contato com a alteridade, se altera e se dissimula, incorporando os valores do outro. Paulo Alves Filho (2010), por outro lado, propõe que, no procedimento tradutório, Anchieta não considere esse ato como um processo de incorporação, mas sim de extirpação, ou seja, uma estratégia de doutrinação. No entanto, não se pode medir até que ponto as "transculturações" constantes dos autos anchietanos são apenas estratégias de conversão do índio ou resultado de uma transfiguração muito mais complexa.

\section{CONSIDERAÇÕES FINAIS}

\footnotetext{
${ }^{8}$ Como antes, a Mãe de Jesus o arruinou e o esmagou. Assim ela me enviou aqui para partir sua cabeça. Defenda-se, besta feroz. Eu o ferirei, falsário. Pronto! Matei Makaxera. O mal não existe mais... Sou Añagupiara!
} 
Pode-se afirmar seguramente que a invenção de uma língua escrita para as línguas indígenas, bem como sua inserção no processo educacional nos séculos XVI, XVII e XVIII, não significou em nenhum momento prestígio aos aspectos da cultura nativa, mas uma estratégia para dirimir diversidades, padronizando o colonizado. O que a Arte de Gramática fez foi estabelecer a essa língua fabricada, denominada Língua-Geral pelos jesuítas, uma sintaxe portuguesa, a fim de adaptar essa nova língua ao seu iminente extermínio. A Língua-Geral é criada para reduzir as diversidades linguísticas e, posteriormente, ser legada ao esquecimento.

Os primeiros letramentos e processos educativos no Brasil significaram uma "conversão da língua" - considerada pelos portugueses "dura e selvagem" - e uma "ressignificação da cultura", uma espécie de canibalismo dos símbolos indígenas para a estratégia catequética. A imposição cultural dos ocidentais se valeu de uma pseudo valoração dos aspectos mais significativos da vida brasílica, dando a ligeira impressão de que os jesuítas, especialmente o padre José de Anchieta, atribuía a este tupi inventado um status de língua oficial da colônia. Verdade é que o chamado "apóstolo do Brasil" não viveu até o decreto que extinguiu de vez a língua nativa como língua ensinada na colônia, no entanto funcionou muito bem como catalizador da empresa colonizadora, que intentava enfraquecer a resistência indígena reduzindo sua complexidade e riqueza culturais.

Eis o que no início deste artigo foi chamado de perspectivismo metalinguístico: a capacidade metalinguística que o mais forte exerce sobre o mais fraco, impondo conceitos como verdade, justiça e civilidade, moldando língua e cultura aos seus padrões, e estabelecendo dicotomias logocêntricas a fim de subjugar os valores nativos aos preceitos do colonizador - o qual representa uma espécie de redentor dos signos "enfraquecidos" dos povos dominados, ofertando a eles benfeitorias como uma escrita, um dicionário, uma gramática, um sistema. Como afirma Friedrich Nietzsche (1999a) um dos vanguardeiros do Perspectivismo -, a vontade de potência é a tendência natural que cada organismo, cada ser possui intrinsecamente, e o que faz com que busque se expandir, através da imposição de suas ações, de sua força. A perspectiva é resultado dessas forças inerentes à vontade de potência: "O perspectivismo é uma complexa forma da especificidade [...]. Minha concepção é que todo corpo específico torna-se senhor do espaço e nele estende sua força (sua vontade de potência)" (Nachlass/FP 1888, 14[186], KSA 13.3739) (NIETZSCHE, 1999a, p. 373).

E, por fim, sobre a vontade irrefreável que o homem ocidental tem de se impor sobre o outro, a clássica assertiva de Nietzsche:

\begin{abstract}
"Perspectivismo". São os nossos desejos que interpretam o mundo: os nossos instintos com seus prós e contras. Cada instinto é uma espécie de sede de domínio, cada um deles possui a sua perspectiva, que sempre deseja impor como norma a todos os outros instintos (Nachlass/FP 1886, 7[60], KSA 12.315) (NIETZSCHE, 1999b, p. 315).
\end{abstract}

\title{
REFERÊNCIAS
}

ALVES FILHO, P. E. As traduções do jesuíta José de Anchieta para o Tupi no Brasil colonial. Revista TradTerm, v. 17, p. 11-30, 2010.

\footnotetext{
${ }^{9}$ Foi adotada para a citação das obras de Nietzsche a convenção proposta pela edição Colli/Montinari das Obras completas do filósofo alemão, quais sejam: GC/FW - A gaia ciência; KSA - Sämtliche Werke. Kritische Studienausgabe; MAI/HHI - Humano, demasiado humano; JGB/BM - Para além de bem e mal; GM/GM - Genealogia da moral; Nachlass/FP - Fragmento póstumo.
} 
ANCHIETA, J. Doutrina cristã, tomo I: catecismo brasílico. São Paulo: Loyola, 1992.

ANCHIETA, J. Artes de gramática da língua mais usada na costa do Brasil. 7. ed. São Paulo: Edições Loyola, 1990.

ANCHIETA, J. Teatro de Anchieta. São Paulo: Loyola, 1977.

BORGES, L. C. A instituição de línguas gerais no Brasil. In: ORLANDI, E. P. (Org.). História das idéias linguiísticas: construção do saber metalingüístico e constituição da língua nacional. Campinas: Pontes; Cáceres: Unemat Editora, 2001. p. 199-222.

BOSI, A. Dialética da colonização. São Paulo: Cia. das Letras, 1992.

BRANDÃO, H. H. N. Uma análise do discurso catequético de Anchieta. 1978. Dissertação (Mestrado em Lingüística) - Universidade de São Paulo, São Paulo, 1978.

CARDIM, F. Tratados da terra e gente do Brasil. 3. ed. São Paulo: Companhia Editora Nacional/MEC, 1978.

CARDOZO, G. L. A questão onomástica no encontro entre jesuítas e índios no Brasil do século XVI: tradução, perspectivismo e metalinguagem. 2016. Tese (Doutorado em Letras/Estudos da Linguagem) Pontifícia Universidade Católica do Rio de Janeiro, Rio de Janeiro, 2016a.

CARDOZO, G. L. A questão da linguagem nas epístolas de Paulo aos romanos e aos coríntios. Saarbrücken: Novas Edições Acadêmicas, 2016b.

DRUMOND, C. Apresentação. ANCHIETA, J. Artes de gramática da língua mais usada na costa do Brasil. 7. ed. São Paulo: Edições Loyola, 1990. p. 7-17

EDELWEISS, F. J. Estudos Tupis e Tupi-Guaranis: confrontos e revisões. Rio de Janeiro: Livraria Brasiliana Editora, 1969.

FRANCA, L. O método pedagógico dos jesuítas: o "Ratio Studiorum" - introdução e tradução. Rio de Janeiro: Livraria Agir Editora, 1952.

MURU, C. Missionari portoghesi in India nei secoli XVI e XVII: L'Arte della lingua Tamil - studio comparato di alcuni manoscritti. Viterbo: Sette Città, 2010.

NAVARRO, E. A. The translation of the first texts to Tupi, the classical indian language in Brazil. Crop Revista da Área de Língua e Literatura Inglesa e Norte Americana, n. 6, p. 51-73, 2001.

NIETZSCHE, F. Sämtliche werke: kritische studienausgabe (KSA, v.13), nachgelassene fragmente 1887-1889. Organização Giorgio Colli, Mazzino Montinari. reed. München: Deutscher Taschenbuch Verlag/de Gruyter, 1999a.

NIETZSCHE, F. Sämtliche werke: kritische studienausgabe (KSA, v.12), nachgelassene fragmente 1885-1887. Organização Giorgio Colli, Mazzino Montinari. reed. München: Deutscher Taschenbuch Verlag/de Gruyter, 1999b.

ROBINSON, D. Translation and empire: postcolonial theories explained. Manchester: St. Jerome, 1997.

RODRIGUES, A. D. Línguas indígenas brasileiras. Brasília: Laboratório de Línguas Indígenas da UnB, 2013.

SILVA, M. V. Alfabetização, escrita e colonização. In: ORLANDI, E. P. (Org.). História das idéias lingüísticas: construção do saber metalingüístico e constituição da língua nacional. Campinas: Pontes; Cáceres: Unemat Editora, 2001. 139-154. 
Guilherme L. Cardozo

SOARES DE SOUSA, G. Tratado descritivo do Brasil em 1587. Disponível em: < http://www.dominiopublico.gov.br/download/texto/me003015.pdf >. Acesso em: 28 jun. 2018.

Recebido em: 28 jun. 2018.

Aprovado em: 19 jul. 2018. 